\title{
KAJIAN POTENSI SAGU SEBAGAI SUMBER PANGAN LOKAL DI NEGERI TUHAHA KECAMATAN SAPARUA TIMUR KABUPATEN MALUKU TENGAH
}

\author{
M. Luhukay ${ }^{1 *}$, R. G. Risamasu ${ }^{1}$, R. Tomasoa ${ }^{2}$ \\ ${ }^{1}$ Program Studi Ilmu Tanah Fakultas Pertanian Universitas Pattimura \\ ${ }^{2}$ Program Studi Agroteknologi Fakultas Pertanian Universitas Pattimura \\ Jln. Ir. M. Putuhena, Kampus Poka, Ambon 97233 \\ *Email : max.hokky02@gmail.com
}

\begin{abstract}
ABSTRAK
Pangan merupakan kebutuhan dasar bagi kelangsungan hidup manusia dan sekaligus bagi keutuhan suatu bangsa sehingga keberadaannya harus tersedia setiap saat dan pemenuhannya harus terpenuhi. Bagi masyarakat pedesaan, pemenuhan kebutuhan pangan selalu bertumpu pada pangan lokal seperti sagu, umbi-umbian, pisang, jagung, sukun dan lain-lain. Sumberdaya pangan lokal yang ada pada setiap daerah seperti sagu misalnya apabila dikelola secara baik dapat membantu memenuhi kebutuhan pangan rumah tangga dan memperkokoh cadangan pangan daerah serta dapat mengurangi ketergantungan pada beras. Penelitian ini bertujuan untuk mengidentifikasi potensi sagu serta pola dan tingkat konsumsi masyarakat terhadap sagu sebagai pangan lokal. Penelitian dilakukan di Negeri Tuhaha Kecamatan Saparua Timur dengan metode survei dan wawancara terstruktur. Hasil penelitian ditemukan luas lahan sagu yang ada di Negeri Tuhaha 167 ha, pohon masak tebang (MT) 24 pohon/ha dan produksi pati basah per pohon sebesar $484 \mathrm{~kg}$. Total produksi pati sagu kering 1122 ton. Jumlah masyarakat yang masih murni mengkonsumsi sagu sebesar $15 \%$, kombinasi sagu, umbian dan pisang sebesar $27 \%$, kombinasi sagu, umbian, pisang dan beras sebesar $32 \%$ dan murni mengkonsumsi beras sebesar $26 \%$.
\end{abstract}

Kata kunci: Potensi sagu, pangan lokal, konsumsi pangan

\section{STUDY POTENTIAL OF SAGOO AS LOCAL FOOD RESOURCES IN NEGERI TUHAHA EAST SAPARUA DISTRICT MALUKU TENGAH REGENCY}

\begin{abstract}
Food is a fundamental necessity for human survival and at the same time for the integrity of a nation so that its existence must be available at all times and its fulfillment must be fulfilled. For rural people in Maluku, food security depends largely on local foodstuffs such as sago, tubers, bananas, corn, breadfruit and others. Local food resources available in most region in Maluku in particular sago, if managed properly can supportstrengthen the needs of household and local food reserves and in turn reduce dependency on rice. This research aims to identify the potential of sago as well as determine the patterns and levels of public consumption against sago as local food. The research was conducted in East Saparua district land Tuhaha with survey methods and structured interviews. The results of the research found 167 haof sago plantation available in Tuhaha. At least 24 tree/Ha mature sago tree stands (MT) which produced484kgs raw starch per tree or 1122 tons dried sago starch. The percentage of local food consumption respectively was $15 \%$ sago, $27 \%$ combination of sago, tubers and banana, 32\%combination of sago, tubers, banana and rice amounted, and $26 \%$ purely rice.
\end{abstract}

Key words: Sagoo potential, local food, food consumption

\section{PENDAHULUAN}

Pangan merupakan kebutuhan dasar bagi kelangsungan hidup manusia dan sekaligus bagi keutuhan suatu bangsa sehingga keberadaannya harus tersedia setiap saat dan pemenuhannya harus terpenuhi. Data Badan Pangan Dunia (FAO) menunjukkan bahwa dari seluruh beras yang beredar di pasar dunia, 80 persennya diserap oleh Indonesia. Hal ini menggambarkan lemahnya perhatian pemerintah 
terhadap potensi pangan lokal yang ada, padahal kurang lebih 60 persen penduduk Indonesia yang hidup di pedesaan kebutuhan pangannya bersumber dari pangan lokal (Subandriyo, 2007). Keberadaan pangan lokal pada setiap daerah diharapkan dapat berperan untuk mengatasi kerawanan pangan, namun kenyataannya pangan lokal sering dilupakan.

Pola konsumsi masyarakat pedesaan yang semula berbasis pangan lokal kemudian telah berubah ke beras merupakan faktor penyebab rentannya kerawanan pangan di setiap daerah pada masa mendatang (Rauf dan Lestari, 2009). Kemudahan untuk mendapatkan beras dengan harga murah melalui kebijakan beras keluarga miskin (RASKIN) semakin memperparah keberadaan pangan lokal di tengahtengah masyarakat.

Sumberdaya pangan lokal yang ada pada setiap daerah seperti sagu misalnya apabila dikelola secara baik dapat membantu memenuhi kebutuhan pangan rumah tangga dan memperkokoh cadangan pangan desa/daerah serta dapat mengurangi ketergantungan pada beras (Louhenapessy, 1992). Hal ini merupakan tantangan sekaligus peluang yang perlu mendapat perhatian serius pemerintah daerah melalui upaya pengelolaan dan pemanfaatan sumberdaya pangan lokal seperti sagu dalam pemantapan ketahanan pangan rumah tangga/individu dan daerah serta nasional (Bantacut, 2011).

Pemerintah menyadari bahwa untuk mencapai ketahanan pangan nasional tidak bisa bertumpu hanya pada beras. Kebijakan pemerintah untuk menetapkan pelaksanaan ketahanan pangan dengan memanfaatkan semaksimal mungkin pangan lokal adalah suatu langkah yang bijak dan tepat (BPTP-Maluku, 2007). Hal ini terungkap dalam Peraturan Presiden Nomor 38 Tahun 2008 Tentang Rencana Kerja Pemerintah Tahun 2009, yang menyatakan bahwa Sagu termasuk salah satu komoditi potensial untuk dikembangkan.

Sagu (Metroxylon sp.) merupakan tumbuhan penghasil pati dengan kandungan karbohidrat yang tinggi $( \pm 85 \%)$, selain dapat dijadikan sebagai sumber bahan pangan, dapat juga dijadikan sebagai bahan baku industri maupun bahan baku energi alternatif (biofuel/bioetanol) (BPPSM, 2009; Santoso, 2017). Keuntungan dalam pengolahan sagu sebagai bahan pangan saat ini dibanding pangan lain yaitu karena (1) potensinya besar, (2) kandungan karbohidrat cukup tinggi dan (3) produksi pati cukup tinggi (Louhenapessy, 1992).

Negeri Tuhaha merupakan salah satu negeri di Kecamatan Saparua Timur yang memiliki potensi hutan sagu cukup luas jika dilihat dari luas Kecamatan itu sendiri. Aktifitas petani pengolah sagu mentah sangat tinggi. Hal ini terlihat dari penjualan sagu mentah di pasar kecamatan dapat mencapai delapan ton setiap bulan. Jalur transportasi baik ke ibu kota kabupaten/kota maupun ke ibu kota provinsi sangat lancar sehingga dapat mempengaruhi pola makan masyarakat setempat. Dengan demikian menarik untuk dikaji peranan sagu sebagai sumber pangan lokal di Negeri Tuhaha dengan tujuan untuk mengidentifikasi potensi sagu serta mengidentifikasi pola dan tingkat konsumsi masyarakat terhadap sagu.

\section{BAHAN DAN METODE}

Penelitian dilaksanakan di Negeri Tuhaha Kecamatan Saparua Timur Kabupaten Maluku Tengah sejak bulan November sampai Desember 2018.

Alat dan bahan yang digunakan untuk menunjang penelitian ini adalah GPS, kompas, abney level/clinometer, altimeter, bor tanah, pacul, sekop, meter roll, buku Muncell soil color chart, pH lapangan, tali nilon, kantong dan karung plastik, daftar quesioner, alat tulis menulis, ember, parutan, penyaring pati sagu, timbangan dan kamera.

Metode penelitian yang digunakan adalah metode survei dengan tingkat pemetaan semi detail. Sebagai petunjuk awal, dilakukan diskusi dengan masyarakat, kepala desa/raja untuk mengetahui lokasi penyebaran lahan sagu. Langkah operasional pelaksanaan kegiatan lapangan adalah sebagai berikut :

1. Pemetaan luas dan penyebaran lahan sagu berdasarkan petunjuk dari masyarakat dengan menggunakan GPS yang dilakukan secara poligon tertutup atau dilakukan secara grid pada lahan sagu.

2. Setelah mendapat sebaran lahan sagu, dibuat blok sampel berukuran 100 x $100 \mathrm{~m}$ pada lahan yang luas dan atau 50 x $50 \mathrm{~m}$ pada lahan yang sempit, dibuat tegak lurus garis pantai. Untuk mempermudah pelaksanaan pekerjaan dalam blok, blok sampel berukuran 100 x 100 m dibagi menjadi 4 kuadran dengan ukuran masing-masing kuadran 50 × $50 \mathrm{~m}$. Pada setiap kuadran dibuat jalur pengamatan dengan jarak antar jalur $10 \mathrm{~m}$ dan panjang jalur $50 \mathrm{~m}$. Pada blok sampel yang berukuran 50 x $50 \mathrm{~m}$, pengamatan dilakukan pada seluruh jalur.

3. Pengamatan secara intensif dalam blok sampel meliputi :

a) Pengamatan jenis sagu, jumlah fase pertumbuhan setiap rumpun (semai, sapihan, tiang, pohon, masak tebang, lewat masak tebang) dan jumlah rumpun.

b) Menghitung produksi pati basah per pohon. Untuk mengetahui produksi pati basah per pohon dilakukan penebangan pohon masak tebang yaitu pada fase jantung, selanjutnya :

1) Pohon sagu dipotong menjadi tual-tual berukuran $1 \mathrm{~m}$. 
2) Pengukuran diameter batang atau lingkaran batang, tinggi batang/pohon dan tebal korteks pada setiap tual.

3) Pengambilan sampel empulur sagu dengan menggunakan pipa besi berukuran diameter $10 \mathrm{~cm}$ (jari-jari $5 \mathrm{~cm}$ ), tinggi $10 \mathrm{~cm}$. Sampel diambil pada setiap tual pada bagian bawah mulai dari tual pertama (bagian pangkal) sampai tual terakhir (bagian ujung).

4) Sampel diparut, diekstraksi, diendapkan selama kurang lebih 1 malam kemudian air endapan dibuang dan ditimbang berat pati basah.

Variabel yang diamati dalam penelitian ini meliputi: (1) produksi sagu dan pati; (2) jenis sagu; (3) proses pengolahan sagu; (4) sistem pengolahan sagu; (5) pola konsumsi; dan (6) kontribusi sagu senagai sumber pangan lokal. Data yang diperoleh dianalisis secara deskriptif sesuai dengan tujuan penelitian.

\section{HASIL DAN PEMBAHASAN}

\section{Produksi Sagu}

Berdasarkan hasil penelitian ditemukan luas lahan sagu di negeri Tuhaha sebesar167 ha dengan jumlah pohon masak tebang (MT) sebanyak 24 pohon/ha.

Untuk mengetahui produksi pati per pohon dilakukan penebangan tiga jenis pohon sagu yang dijadikan sebagai sampel yaitu sagu tuni, molat dan ihur. Produksi pati per pohon selain tergantung kondisi lahan tempat tumbuh, juga tergantung pada diameter batang dan tinggi batang bebas daun (Flach and Schuiling, 1988; Louhenapessy, 1994). Hasil perhitungan didapati bahwa produksi pati basah sagu tuni adalah $631 \mathrm{~kg} /$ pohon, sagu molat $535 \mathrm{~kg} /$ pohon dan sagu ihur510 kg/pohon. Dengan demikian nilai rata-rata produksi pati basah per pohon adalah sebesar $560 \mathrm{~kg} /$ pohon.

Berdasarkan luas lahan sagu, jumlah pohon masak tebang (MT) per hektar dan produksi pati basah per pohon $(\mathrm{kg})$ dapat dihitung potensi produksi pati sagu di Negeri Tuaha dengan persamaan :

$$
\mathrm{P}=\mathrm{L} \text { x MT x Pp }
$$

$$
\begin{array}{ll}
\mathrm{P} & =\text { Produksipati }(\mathrm{kg} / \mathrm{ton}) \\
\mathrm{L} & =\text { Luas lahan sagu (ha) } \\
\mathrm{MT} & =\text { Rata-rata pohon masak tebang/ha (pohon) } \\
\mathrm{Pp} & =\text { Produksi pati basah/pohon }(\mathrm{kg} / \mathrm{ton})
\end{array}
$$

Dengan demikian potensi produksi pati sagi di Negeri Tuhaha sebesar 167 × 24 × $560 \mathrm{~kg}=2.244 .480$ kg pati basah atau $2.244,5$ ton pati basah atau 1.122 ton pati kering.

\section{Jenis Sagu}

Jenis sagu sagu yang ditemukan di lokasi penelitian adalah Sagu putih/sagu tuni (Metroxylon rumpii Mart.), Sagu merah/sagu ihur (Metroxylon sylvestre Mart.), Sagu Makanaru (Metroxylon longispinum Mart.), Sagu makanatol/duri rotan (Metroxylon microcanthum Mart.) dan Sagu molat (Metroxylon sagus Rottb.) (Louhenapessy dan Luhukay, 2011). Kelima jenis sagu tersebut tumbuh dan berkembang bercampur menjadi satu dengan persentasi terbesar berturut turut adalah sagu tuni, sagu ihur, sagu molat, sagu makanaru dan sagu duri rotan.

\section{Proses Pengolahan Sagu}

Proses pengolahan sagu terdiri dari : pengolahan tradisional, pengolahan semi mekanis, pengolahan mekanis sederhana dan pengolahan full mekanis. Proses pengolahan sagu yang ditemukan pada lokasi penelitian hanya pengolahan semi mekanis sedangkan proses pengolahan tradisional sudah ditinggalkan dengan alasan banyak memakan waktu dan tenaga, sedangkan pengolahan mekanis sederhana dan full mekanis belum ada.

Tahapan dalam proses pengolahan sagu semi mekanis dimulai dari penetapan pohon MT (siap panen), pembersihan lokasi penebangan, persiapan goti, penebangan, pemotongan pohon sagu menjadi tual-tual berukuran $50 \mathrm{~cm}$,pembelahan tual menjadi lempengan tual, penghancuran empulur (pemarutan), ekstraksi, pengendapan pati dan pengemasan.

Umumnya penebangan dan pemotongan pohon sagu menjadi tual-tual berukuran kurang lebih $50 \mathrm{~cm}$ sudah menggunakan chain saw, sedangkan pembelahan tual menjadi lempengan tual dilakukan dengan kapak. Proses penghancuran empulur umumnya menggunakan mesin parut. Penyaring yang dipasang pada sahani menggunakan kain sifon dan pengendapan pati menggunakan terpal plastik. Pengemasan pati sagu dimasukan kedalam keranjang yang terbuat dari anyaman daun sagu yang disebut tumang.

\section{Sistem Pengolahan Sagu}

Sistem pengolahan sagu pada lokasi penelitian terdiri dari dua bentuk yaitu sistem olah sendiri dan sistem bagi hasil. Sistem olah sendiri biasanya dilakukan oleh pemilik lahan sagu itu sendiri sedangkan sistem bagi hasil adalah sistem pengolahan sagu yang dilakukan oleh mereka yang tidak memiliki lahan sagu bekerja sama dengan pemilik lahan sagu kemudian diatur sistem pembagian hasilnya secara bersama-sama. 
Ada dua bentuk sistem bagi hasil yaitu ma'ano dan babalu. Menurut Louhenapessy dkk. (2010), ma'ano adalah apabila seseorang mengolah sagu milik keluarga lain dalam negeri atau desa yang sama dan hasilnya akan dibagi antara pemilik dan pengolah, yang persentasinya disepakati bersama. Umumnya pembagian hasil yang disepakati adalah $10 \%$ untuk pemilik mesin parut, $45 \%$ untuk pemilik lahan sagu dan $45 \%$ untuk pengolah sagu. Sedangkan babalu adalah satu hubungan antara masyarakat antar pulau dalam aspek pengolahan sagu dimana satu keluarga dari pulau lain datang mengolah sagu di pulau lain. Umumnya hasil babalu seluruhnya diberikan kepada keluarga yang datang mengolah ada pula dengan cara pembagian tetapi biasanya prosentasi terbesar kepada pengolah.

\section{Pola Konsumsi}

Untuk menganalisis pola konsumsi masyarakat pada lokasi penelitian dilakukan wawancara terstruktur terhadap responden yang terdiri dari petani, pegawai, wira usaha dan tokoh masyarakat (raja dan atau guru). Penilaian dilakukan berdasarkan jenis pangan yang dikonsumsi dalam persen. Pangan yang dikonsumsi dibagi menjadi 4 pola yaitu :

a. Murni mengkonsumsi sagu.

b. Kombinasi sagu, umbian dan pisang.

c. Kombinasi sagu, umbian, pisang dan beras.

d. Murni mengkonsumsi beras.

Hasil analisis data quesioner mengenai pola konsumsi masyarakat pada lokasi penelitian disajikan pada Tabel 1.

Tabel 1. Persentasi masyarakat pemakan sagu, kombinasi sagu, pisang umbian, kombinasi sagu, pisang, umbian dan beras serta beras pada lokasi penelitian

\begin{tabular}{rlc}
\hline No. & \multicolumn{1}{|c}{ Pangan Yang Dikonsumsi } & $\begin{array}{c}\text { Jumlah } \\
(\%)\end{array}$ \\
\hline 1. & Sagu & 15 \\
2. & Kombinasi Sagu, Umbian dan & 27 \\
& Pisang & 32 \\
3. & Kombinasi Sagu, Umbian, & \\
& Pisang dan Beras & 26 \\
4. & Beras \\
\hline
\end{tabular}

Dari data tersebut di atas ternyata kombinasi sagu, umbian, pisang dan beras merupakan persentasi tertinggi pola makan masyarakat. Hal ini dapat dimaklumi karena lokasi penelitian memiliki keragaman pangan lokal yang cukup tinggi seperti umbi-umbian dan pisang (Latuhihin, 1995). Selain itu, program beras untuk orang miskin (raskin) terbilang cukup lancar menyebabkan kebutuhan beras selalu dapat terpenuhi. Jumlah masyarakat yang masih murni mengonsumsi sagu sebesar $15 \%$, terutama orang tua dan petani pengolah sagu sedangkan anak-anak mudah sangat sedikit yang mengonsumsi sagu. Sagu yang dimaksud di sini adalah papeda dan sagu lempeng. Jumlah masyarakat yang mengonsumsi kombinasi sagu, umbian dan pisang sebesar $27 \%$, kombinasi sagu, umbian, pisang dan beras sebesar $32 \%$ dan murni mengkonsumsi beras sebesar $26 \%$.

Faktor lain yang turut berpengaruh dalam pola konsumsi masyarakat di Negeri Tuhaha adalah karena akses pasar baik pasar kecamatan, pasar kabupaten maupun pasar provinsi yang begitu mudah dijangkau.

\section{Kontribusi Sagu Sebagai Sumber Pangan Lokal Dalam Menunjang Ketahanan Pangan}

Dalam Undang-Undang Negara Republik Indonesia No. 7 Tahun 1996 kemudian diperbaharui dengan Undang-Undang Republik Indonesia Nomor 18 Tahun 2012 tentang Pangan, yang dimaksud dengan ketahanan pangan adalah kondisi terpenuhinya pangan bagi rumah tangga yang tercermin dari tersedianya pangan yang cukup, baik jumlah maupun mutunya, aman, merata dan terjangkau. Hal ini mengisyaratkan bahwa pemantapan ketahanan pangan akan lebih efektif apabila dimulai dari tingkat rumah tangga. Untuk itu, perlu diusahakan ketersediaan pangan yang bermutu, beragam dan terjangkau oleh seluruh anggota keluarga.

Salah satu upaya yang paling tepat adalah dengan mengembangkan pangan lokal baik berupa komoditi primer maupun sekunder sebagai bahan pangan yang berasal dari pangan nabati dan hewani. Hal ini sangat beralasan karena kenyataan yang terjadi saat ini menunjukkan bahwa produktivitas padi sudah tidak mampu menopang kebutuhan beras secara nasional sehingga untuk memenuhi kekurangan kebutuhan beras nasional pemerintah menerapkan program import beras sebagai program wajib yang dilakukan setiap tahun.

Selain itu, dengan laju pertumbuhan penduduk secara nasional setiap tahun yang tidak sebanding dengan kenaikan produktivitas padi per tahun merupakan tantangan berat yang harus dihadapi. Berdasarkan data Badan Ketahanan Pangan Kabupaten Maluku Tengah pada tahun 2018, konsumsi beras per kapita per tahun untuk penduduk di lokasi penelitian (Kecamatan Saparua) sebesar 77,4 kg/kapita/tahun. Dengan demikian jika jumlah penduduk Negri Tuhaha sebesar 2.747 jiwa maka total kebutuhan beras setiap tahun untuk Negeri Tuhaha adalah sebesar 212,6 ton/tahun tergolong cukup besar.

Kenyataan di atas memberikan gambaran bahwa apabila masyarakat Negeri Tuhaha dalam pemenuhan kebutuhan pangannya hanya bergantung pada beras, maka masalah kerawanan pangan akan mengancam pada tahun-tahun mendatang. Dengan 
demikian diperlukan suatu komitmen bersama antara pemerintah dan masyarakat dalam pemanfaatan pati sagu dan pangan lokal lainnya sebagai sumber pangan.

Nilai konversi sagu terhadap beras (NKSB) dapat dihitung berdasarkan kandungan kalori dalam $100 \mathrm{~g}$ beras dibagi kandungan kalori dalam $100 \mathrm{~g}$ sagu dengan persamaan berikut :

$$
N K S B=\frac{\text { Kandungan kalori } / 100 \mathrm{~g} \text { beras }}{\text { Kandungan kalori } / 100 \mathrm{~g} \text { sagu }}
$$

Berdasarkan hasil perhitungan Luhukay (2013), ditemukan nilai konversi sagu terhadap beras berkisar antara $1,01-1,74$. Artinya bahwa $1 \mathrm{~kg}$ beras setara dengan 1,01 - 1,74 kg pati sagu kering. Dari total produksi pati sagu kering di Negeri Tuhaha sebesar 1.122 ton, dapat menutupi kekurangan kebutuhan beras sebanyak 645 - 1.111 ton jika masyarakat mau berkomitmen untuk mengganti pemenuhan kebutuhan karbohidrat pada sagu.

\section{SIMPULAN}

Dari hasil kajian lapangan, beberapa hal yang dapat disimpulkan yaitu total produksi pati sagu kering sebesar 1.122 ton. Jumlah masyarakat yang masih murni mengkonsumsi sagu sebesar 15\%, kombinasi sagu, umbian dan pisang sebesar $27 \%$, kombinasi sagu, umbian, pisang dan beras sebesar $32 \%$ dan murni mengkonsumsi beras sebesar $26 \%$. Dari total produksi pati sagu kering di Negeri Tuhaha sebesar 1.122 ton, total kebutuhan beras yang dapat diganti dengan pati sagu kering adalah sebesar $645-1.111$ ton.

\section{DAFTAR PUSTAKA}

Bantacut, T. 2011. Sagu: Sumberdaya untuk Penganekaragaman Pangan Pokok. Jurnal Pangan. 20(1): 27-40.

BPPSM. 2009. Laporan Akhir Inventarisasi Potensi dan Pemetaan Sagu Kecamatan Bula Kabupaten Seram Bagian Timur Provinsi Maluku.

BPTP-Maluku. 2007. Identifikasi Potensi dan Peluang Pengembangan Komoditas Tanaman Pangan Spesifik Lokasi Untuk Mendukung Sistem Ketahanan Pangan Lokal di Kabupaten Maluku Tenggara Barat. Kerjasama BPTPMaluku dengan Dinas Pertanian Kabupaten Maluku Tenggara Barat.
Flach, M., and D. L. Schuiling. 1988. Revival of An Ancient Strach Crop; A Review of The Agronomi of The Sago Palm. Dept. of Tropical Croop Science Agric. Univ. of Wageningen The Netherlands.

Latuhihin. 1995. Evaluasi Kesesuaian Lahan Pulau Saparua Kabupaten Maluku Tengah Untuk Beberapa Komoditi Pertanian. [Skripsi]. Fakultas Pertanian Universitas Pattimura. Ambon.

Louhenapessy. J.E. 1992. Sagu Di Maluku (Potensi, Kondisi Lahan Dan Permasalahannya). Prosiding Simposium Sagu Nasional. Faperta UNPATTI Ambon.

Louhenapessy. J.E., 1994. Evaluasi Dan Kesesuaian Lahan Bagi Sagu (Metroxylon Spp). [Disertasi]. Program Doktor Universitas Gadjah Mada. Yogyakarta.

Louhenapessy, J.E., M. Luhukay, S.M. Talakua, H. Salampessy, dan J. Riry. 2010. Sagu Harapan Dan Tantangan. Penerbit Bumi Aksara. Jakarta.

Louhenapessy J.E., dan M. Luhukay. 2011. Usulan Pelepasan Varietas Sagu Molat Maluku. Kerjasama Dinas Pertanian Provinsi Maluku dengan BBP2TP Ambon Ditjen Perkebunan-Kementerian Pertanian.

Luhukay, M. 2013. Pengkajian Potensi Sagu Sebagai Sumber Pangan Lokal Dalam Menunjang Ketahanan Pangan Nasional di Kabupaten Seram Bagian Timur. [Tesis]. Program Pascasarjana Universitas Gadjah Mada. Yogyakarta.

Rauf, A.W., dan M.S. Lestari. 2009. Pemanfaatan Komoditas Pangan Lokal Sebagai Sumber Pangan Alternatif Di Papua. Jurnal Litbang Pertanian. 28(2):54-62.

Santoso, A.D. 2017. Potensi dan Kendala Pengembangan Sagu sebagai Bakan Pakan, Pangan, Energi dan Kelestarian Lingkungan di Indonesia. Jurnal Rekayasa Lingkungan (JRL). 10(2): 51-57.

Subandriyo, T. 2007. Karawang (Kembali) Bergoyang”, Kompas, Opini, [26/02/2019]. 